\title{
Isolation of lactic acid bacteria (LAB) species as probiotic from intestinal contents of common carp Cyprinus carpio $\mathrm{L}$.

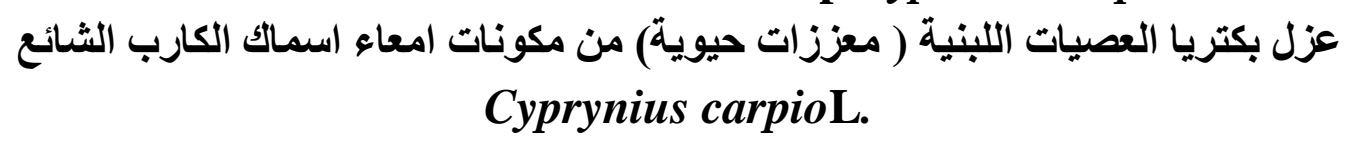

Jamal K.H.Al-Faragi

Sundus A.A.Alsaphar

Veterinary College/ Baghdad University

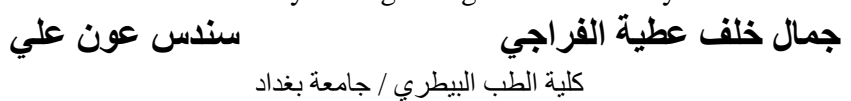

\section{Abstract}

The presence of lactobacilli were investigated in the intestine of 50 fish specimens common carp cyprinus carpio weight rang between 400-1500g in weight from commercial farms in north of Baghdad through period of September to December 2010. All isolates were Gram positive ,catalase negative short rod usually non motile and non sporulating bacteria that produce lactic acid as a major or sole product of their fermentative metabolism.The obtained data showed that various species of lactic acid bacteria were found with high levels in total number about $10^{4}-10^{7} \mathrm{CFU} / \mathrm{g}$ of intestinal content, physiological and biochemical characteristics of 8 strains isolated from intestine $\mathrm{J1}, \mathrm{J3}, \mathrm{J4}$, J6, J7, J8, J9, J10 that can be categorized in two metabolic group facultative and obligate heterofermentation, also all isolates were resistante to all antibiotic sensitivity OA2A -p Disc except isolates $\mathrm{J1}, \mathrm{J3}, \mathrm{J4}$, J8, J9 were sensitive to erythromycin in concentration $60 \mathrm{mcg}$.The aim of this study was to characterize of lactic acid bacteria isolated from the gastrointestinal tract of common carp Cyprinus carpio to be used as probiotic.

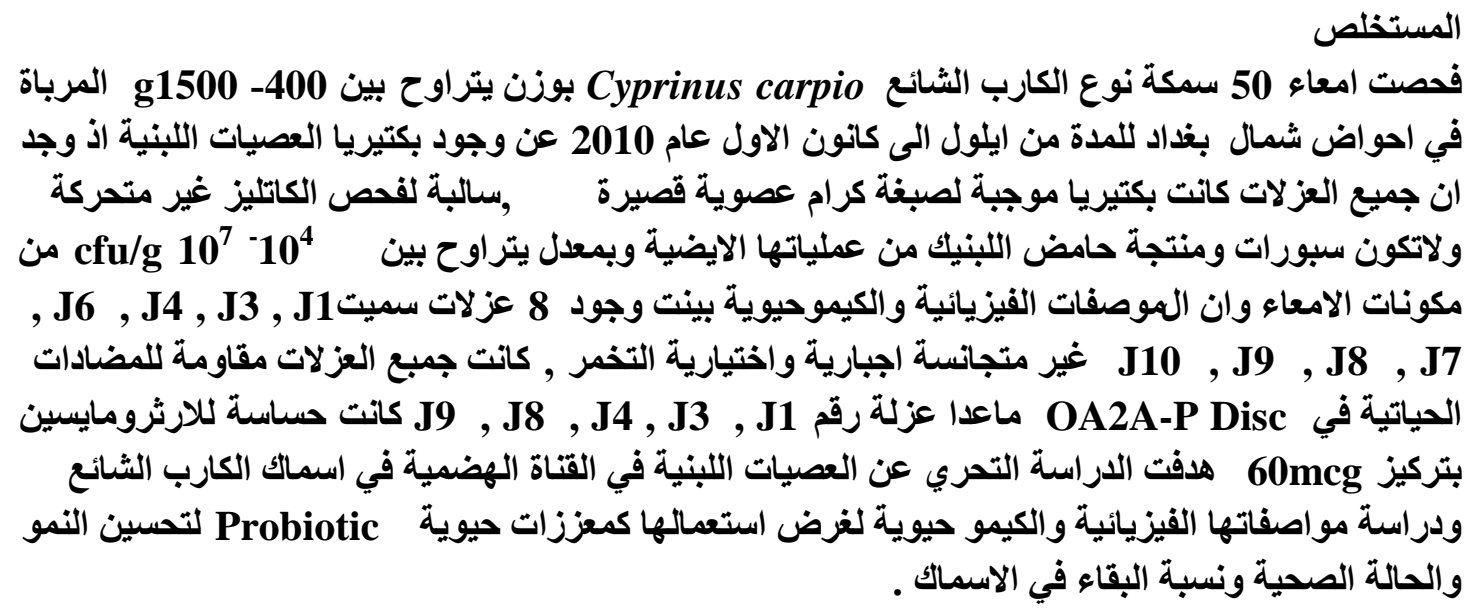

\section{Introduction}

Lactic acid bacteria are gram positive, non spore forming and catalase negative rods or cocci produce circular white and waxy colonies that ferment various carbohydrates mainly to lactate and acetate and various amino-acids can utilize but not usually reduce nitrate, Vitamins and minerals are essential for their growth [1] are commonly associated with nutritious environments like food. decaying material and the mucosal surfaces of the gastrointestinal and urogenital tract [1,2,3].Lactic acid bacteria are also part of normal intestinal flora of fish [4]. most of the evidences come 
from salmonid species $[4,5,6]$ Few studies have described lactic acid bacteria in other fishes [7,12]. [7] described the presence of lactic acid bacteria including lactobacillus in the intestines of various fish species at larvae fry and fingerling stages inhabiting ponds in Ukraine. They give information on the changes in their composition as a function of the season of the year and life stage of the fish .It was discussed that some human activities like artificial feeding of fish in ponds would have had an effect on the bacterial companian and load like common carp Cyprinus carpio» which showed the highest content of lactic acid bacteria in intestine

The distribution of lactic acid bacillus in the intestinal content of river fish and reported that various species of lacto bacilli were present in relatively high numbers in the intestines of edible fresh water fish from the river, specially in warm season but in low numbers in cold season[8] . [9]was pointed out studied the composition of intestinal lactic acid bacteria in carp fish and show that predominant LAB was Lactococcus lactis in July and Lactococcus raffinolactis in December and yearlong analysis of changes in LAB composition was performed in common carp from April 2002 to March 2003 . The predominant LAB was L. lactis in summer when water temperature was above $20 \mathrm{c}$ and L. raffinolactis in winter, when water temperature was ranges between $4-10^{\circ} \mathrm{C}$.

The aim of present study was to characterization of LAB isolated from intestines of of the common carp «Cyprinius carpio» of commercial farms near Baghdad.

\section{Materials and methods}

\section{Fish bacterial media and reagents}

\section{Fish}

Several groups of adults common carp were obtained from commercial fish farms in the north of Baghdad from September 2010- to December 2010 and maintained in aquarium filled with tap water at $21 \mathrm{c}^{\circ}$.

\section{Chemicals and media}

Analytical grade chemicals and dyes were obtained from Al-Kindi company for production of veterinary vaccines and drugs, bacteriological media were obtained from oxoide UK which include set of biochemical media, blood agar base,,Nutreint agar, gas generating Kit and sens test disk from lamb GT. Manchester; England finally MRS media were obtained from Himedia ,India .

\section{Isolation of bacterial strain}

Various samples of the common carp «Cyprinus carpio» of commercial farm in the north of Baghdad (average between 400-1500 $\mathrm{g}$ in weight). They were brought to the laboratory alive and sacrificed. The abdomen surfaces were thoroughly scrubbed with an alcohol (70\% ethanol) and aseptically dissected to remove the intestines. The intestines were opened by longitudinal incision and thoroughly flushed with sterilized chilled normal saline solution (NSS) to remove feed materials, dirt and other impurities. The intestines were weighted macerated with sterile glass rod and homogenized in sterile NSS (1:10 wet/vol) using a vortex mixer. Samples of the thoroughly macerated and homogenized intestines were serially diluted in NSS and aseptically plated by pour plate technique on MRS agar and incubated anaerobically at $30^{\circ} \mathrm{C}$ for $2-3$ days. 
Well isolated colonies were picked up less than 10 colonies per each plate and all the samples were counted according to the method described by [10] and transferred to MRS broth. They were propagated twice and streaked on MRS agar to check the purity of the isolates and then stored in MRS soft agar $0.5 \%$ overlaid with $50 \%$ glycerol at $-20{ }^{\circ} \mathrm{C}$ and pure culture were freeze dried and stored at $-20^{\circ} \mathrm{C}$ the isolates maintained in frozen stocks were propagated twice in MRS broth and used for further study, these were inoculated in to MRS broth and incubated at $30^{\circ} \mathrm{C}$ for $18 \mathrm{~h}$.

\section{Characterization and Differentiation of LAB}

Isolated strains were gram stained and examined microscopically for cellular morphology and Gram-stain phenotype,catalyse activity was tested by spotting colonies with 3\% hydrogen peroxide. Growth was assayed in MRS broth at 4, 10, $25,30,35$ and $45 \mathrm{c}^{\circ}$ as well as $\mathrm{pH} 4.0,5.0,6.5,8.5$ and 9.0 incubated at $30 \mathrm{c}^{\circ}$. Salt tolerance was tested with $6.5 \%, 10,15 \% \mathrm{w} / \mathrm{v} \mathrm{NaCl}$ in MRS broth production of acid and $\mathrm{CO} 2$ from glucose was tested in MRS broth containing Darhams tabe with citrate omitted[1]production of Ammonia in MRS broth omitting glucose and meat extract while containing $0.3 \%$ Arginine and $0.2 \%$ Sodium.citrate replacing ammonium citrate was monitored using Nesslers reagent. Assays for gelatin hydrolysis and nitrate reduction[11]. Ability to ferment various carbohydrates was evaluated using MRS broth supplemented with filter sterilized sugar solutions to final concentration of $1 \%$ $\mathrm{w} / \mathrm{v}$ and $0.004 \%$ phenol red without glucose and meat extract.

\section{Antibiogram of LAB isolates}

The isolates were inoculated into MRS broth individually and incubated for $24 \mathrm{hr}$ about $25 \mathrm{ml}$ of MRS agar was seeded with the cultures of LAB isolates $10^{6} \mathrm{CFU} / \mathrm{ml}$ mixed well. Poured in to sterile petriplates and stored at $4 \mathrm{c}^{\circ}$ for $1 \mathrm{hr}$ to solidify the media (OA21-P) antibiotics in a single ring were placed upside down pressed on the top of the agar plates and kept again at $4 \mathrm{c}^{\circ}$ for $1 \mathrm{hr}$ the plate were incubated at $30 \mathrm{C}^{\circ}$ for $24 \mathrm{hr}$. and $48 \mathrm{hr}$ resistance was defined as the absence of a growth inhibition zone around the discs.

\section{Results and Discussion}

Intestinal content of all fish sample analyzed for the presence of lactobacilli. Counts of intestinal lactic acid bacteria for common carp detected at the range of $10^{4}-10^{7}$ CFU/g found in table (1) these results were supported by[12][13];they estimated lactic acid bacteria counts $10^{7}$ to $10^{8} \mathrm{CFU} / \mathrm{g}$ in the intestine of common carp , while [14] showed the count of intestinal lactobacillus spp for Persian sturgeon and beluga were detected at the rang of approximately $10^{5.3}$ to $10^{6.4} \mathrm{CFU} / \mathrm{g}$ respectively but [6] found the count of LAB on farm fish was $10^{0}-10^{3} \mathrm{CFU} / \mathrm{g}$ the reasons of all these different result were explained the effect of fish species, life stage of the fish, some human activities like artificial feeding in ponds and also season of the year [9] All the 8 isolates bacteria were found Gram positive while the morphology was coccobacilli arranged in small chain contain 2-6 cells or as a single tetrad and paired cell physiological behavior of all isolates is present in Table(2). 
Table (1): Count of LAB isolates according to date and weight of sample common carp Cyprinus carpio

\begin{tabular}{|c|c|c|c|c|c|}
\hline $\begin{array}{l}\text { Sample } \\
\text { number }\end{array}$ & Isolates & Date & $\begin{array}{l}\text { Avareg weight } \\
\text { of sample }\end{array}$ & $\begin{array}{l}\text { Morphology of } \\
\text { LAB isolation }\end{array}$ & $\begin{array}{c}\text { Count of } \mathrm{LAB} \\
\text { isolation per gram }\end{array}$ \\
\hline 1 & J1 & September & $750-850$ & Coccobacilli & $9 \times 10^{6} \mathrm{cfu} / \mathrm{g}$ \\
\hline 2 & nil & September & $500-650$ & nil & nil \\
\hline 3 & J3 & October & $400-500$ & Coccobacilli & $7 \times 10^{7} \mathrm{cfu} / \mathrm{g}$ \\
\hline 4 & J4 & October & $400-550$ & Coccobacilli & $3.5 \times 10^{7} \mathrm{cfu} / \mathrm{g}$ \\
\hline 5 & nil & October & $450-600$ & nil & nil \\
\hline 6 & J6 & October & $500-740$ & Coccobacilli & $2 \times 10^{7} \mathrm{cfu} / \mathrm{g}$ \\
\hline 7 & J7 & October & $600-750$ & Coccobacilli & $9 \times 10^{6} \mathrm{cfu} / \mathrm{g}$ \\
\hline 8 & J8 & November & $1000-1350$ & Coccobacilli & $3 \times 10^{5} \mathrm{cfu} / \mathrm{g}$ \\
\hline 9 & J9 & December & $1200-1500$ & Coccobacilli & $7 \times 10^{4} \mathrm{cfu} / \mathrm{g}$ \\
\hline 10 & $\mathbf{J 1 0}$ & December & $1100-1150$ & Coccobacilli & $1 \times 10^{4} \mathrm{cfu} / \mathrm{g}$ \\
\hline
\end{tabular}

Table (2): Physiological properties of lactic acid bacteria isolates.

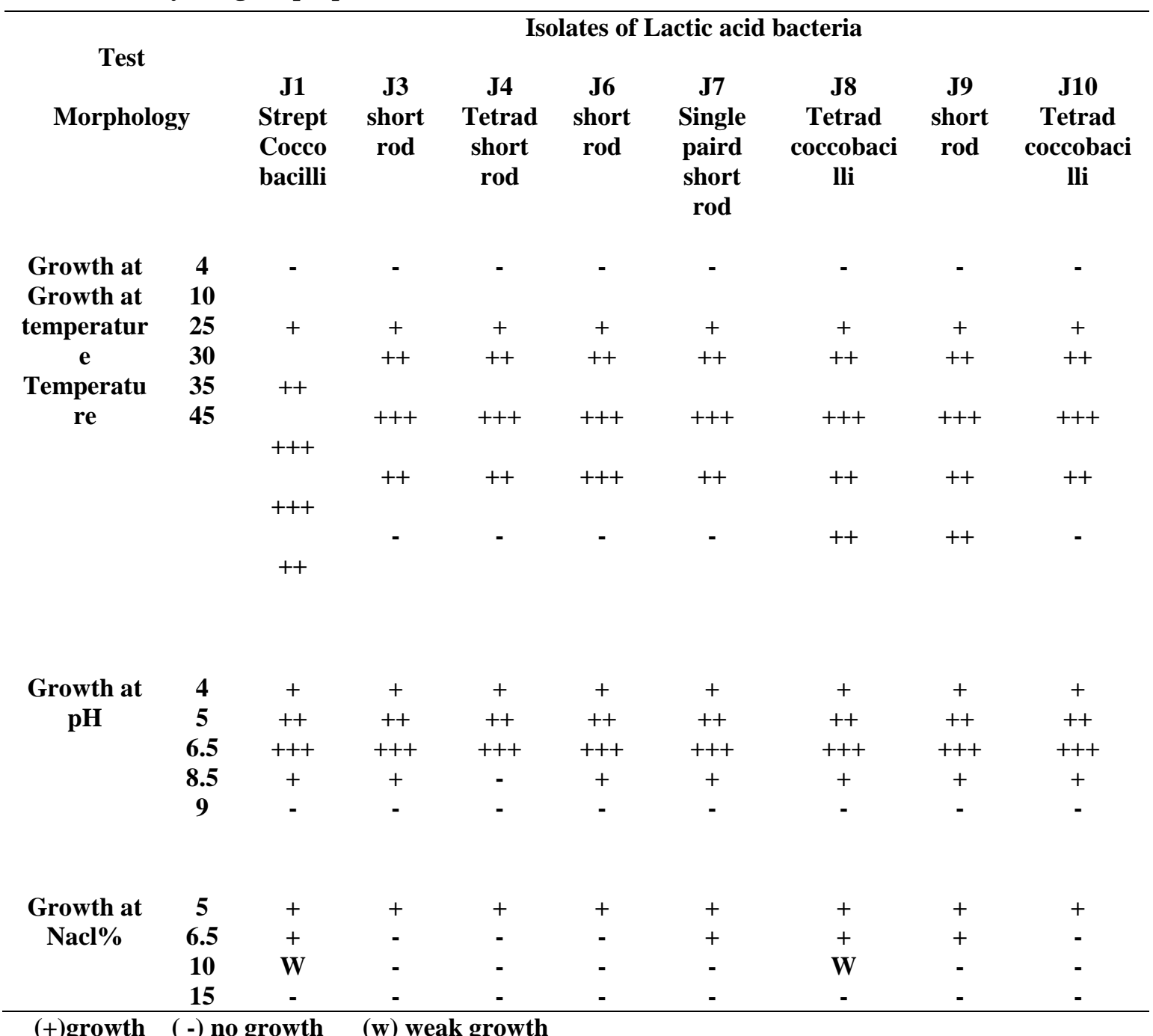

Luxurious growth was observed for all 8 isolates at 30 and $35 \mathrm{C}^{\circ}$ while weak growth was observed at $10 \mathrm{C}^{\circ}$ and no growth was observed at $45 \mathrm{C}^{\circ}$ for isolates $\mathrm{J} 3, \mathrm{~J} 4, \mathrm{~J} 6, \mathrm{~J} 7$, L10. 
The results are shown in the same table; effect of different $\mathrm{pH}$, Nacl concentration (salt tolerance) on the growth Biochemical as well as carbohydrate fermentation and behavior of these isolates against various antibiotics were also found in table $(3,4,5)$.

Table (3): Biochemical properties of LAB isolate

\begin{tabular}{|c|c|c|c|c|c|c|c|c|}
\hline Test & & & & Bacteri & isolate & & & \\
\hline & J1 & J3 & J4 & J6 & J7 & J8 & J9 & J10 \\
\hline Gram stain & G+ev & G+ev & G+ev & $\mathbf{G}+\mathbf{e v}$ & $\mathbf{G}+\mathbf{e v}$ & G+ev & G+ev & G+ev \\
\hline Motility & - & - & - & - & - & - & - & - \\
\hline Spore forming & - & - & - & - & - & - & - & - \\
\hline Catalase & - & - & - & - & - & - & - & - \\
\hline Oxidase & - & - & - & - & - & - & - & - \\
\hline $\begin{array}{c}\text { Gelatin } \\
\text { hydrolysis }\end{array}$ & - & - & - & - & - & - & - & - \\
\hline $\begin{array}{c}\text { Starch } \\
\text { hydrolysis }\end{array}$ & - & - & - & - & - & - & - & - \\
\hline $\begin{array}{c}\text { CaCO3 0.8\% } \\
\text { lyses }\end{array}$ & + & + & + & + & + & + & + & + \\
\hline $\begin{array}{l}\text { CO2 production } \\
\text { from glucose }\end{array}$ & - & - & - & - & - & + & + & + \\
\hline $\begin{array}{c}\text { Nitrite } \\
\text { reduction }\end{array}$ & - & - & - & - & - & - & - & - \\
\hline
\end{tabular}

(+) growth ( - ) no growth

Table(4): Carbohydrate Utilization of LAB isolates

\begin{tabular}{|c|c|c|c|c|c|c|c|c|}
\hline \multirow[t]{2}{*}{ Carbohydrates } & \multicolumn{8}{|c|}{ Bacteria isolates } \\
\hline & $\mathbf{J 1}$ & $\mathbf{J 3}$ & J4 & J6 & J7 & $\mathrm{J} 8$ & J9 & $\mathbf{J 1 0}$ \\
\hline Glucose & + & + & + & + & + & + & + & + \\
\hline Trehalose & + & + & + & + & + & + & + & + \\
\hline Dextrine & + & + & + & - & + & + & + & + \\
\hline Inuline & $+*$ & + & $+{ }^{*}$ & $t^{*}$ & $+*$ & - & + & + \\
\hline Lactose & + & + & + & + & $+*$ & + & + & + \\
\hline Sorbitol & + & $+*$ & $+*$ & $t^{*}$ & + & $+*$ & + & + \\
\hline Adintol & + & $+{ }^{*}$ & $+{ }^{*}$ & $+{ }^{*}$ & + & $+*$ & $+*$ & $+{ }^{*}$ \\
\hline L-arabinos & - & - & - & N.R & - & - & - & - \\
\hline Sucrose & + & + & + & + & + & - & + & + \\
\hline Dolcitol & + & $+*$ & + & $+*$ & $+*$ & $t^{*}$ & + & + \\
\hline Galactose & $+{ }^{*}$ & $+{ }^{*}$ & $+{ }^{*}$ & + & - & - & $t^{*}$ & - \\
\hline Sorbitos & - & - & - & - & + & - & + & + \\
\hline Raffinos & + & + & + & + & + & + & + & + \\
\hline Cellulose & - & - & - & - & + & - & - & + \\
\hline Mannitof & + & + & + & + & + & + & - & + \\
\hline Ftructose & + & + & + & + & + & + & + & + \\
\hline Mannose & + & + & + & + & $+*$ & $+*$ & + & $+{ }^{*}$ \\
\hline Maltose & + & + & + & + & + & + & $+{ }^{*}$ & + \\
\hline
\end{tabular}
(+) ferment
(-) Not ferment
$(+*)$ delayed ferment more than $24 \mathrm{~h}$

(NR) no reaction 
On the baseis of morphological, physiological and biochemical characters as well as sugar utilization all isolates identified were to the genus lactobacillus but could not be assigned to any particular species by these characters it is interesting to note that the majority of lactic acid bacteria spp that have been isolated from fish were those species which were commonly found on meat animals and human [1]. [14] reported that lactobacilli found in their study were relatively similar to the species described [8] These uthors reported L. alimentarias, L.coryneformis, L.casei, L.sakei, L.pentosns, L.plantarum, L. bevies and L.oris, as lactobacilli presented in the intestinal content of studied fish while [15] found the occurance of typical lactobacilli as described by [1] were rare in fish this signified the need for proper classification for lactic acid bacteria from fresh water fish

In this study Most lactobacillus examined had the capacity to ferment lactose and galactose.Most lactobacilli are able to ferment lactose by uptake of this disaccharide by a specific permease and splitting it by $\mathrm{s}$. galactosidase for further phosphorylation of galactose and glucose [1]. Because lactose is only present in milk and milk derivatves, it is possible that these strains have evolved from environments related with mammals, as was suggested for other lactose positive lactobacillus [16 ]. lactose may be presnt or was present in the environment as a waste resulting from livestock production and disposal effluents from dairy factories another component often fermented by the strains was the amino-sugar N- acetyl - glucosamine . a compound present in peptidoglycans, in blood, chitin and as one of the main constituents of mucus in the gastrointestinal tract [17] The carbohydrate and protein constitutes above $40 \%$ of the weight of the mucus [18] or higher values [17].

Fish at all life stages may expose to the bacteria from the environment some of them are detrimental and others are beneficial. Current methods for control of pathogens in the fish farms should be improved by studying the beneficial bacteria. As lactobacillus has many documented health effect [19]. And naturally present in the gastrointestinal tract of man and animals [20] we started studies aimed to investigate the intestinal lactobacillus in fish with the goal of selecting a strain to be used as a feed supplement for warm fresh water fish. Knowledge on the presence of lactobacillus as a natural flora in fish may lead to further application to improve to improve growth performance, survival rate and healthy of fish.

\section{References}

1. Kandler,O and Weiss, N. (1986).Genus Lactobacillus beijerinch(901,212. In:sneath, PHA; Mair, NS:shavpe ME and Hot .JG(eds.)Bergeys manual of systematic bacteriology.V . 2, Baltimore: Williams and Wilkins,: 1209-1234.

2. Havenaar, R; Ten Brink, B .and Huis int Veld , JHJ .(1992). Selection of strains for probiotic use. in : Fuller, R.(ed), probiotics: The scientific basis (Ist Edn. ),London chpman and Hall,: 209-224.

3. Walstra, P; Geurts, TJ; Noomen, A; Jellema, A .and van Boekel, MAJS. (1999). Dairy technology, principles of milk properties and processes. New York, Marcel Dekker, Inc., 727.

4. Ringo, E. and Gatesoupe,FJ.(1998).Lactic acid bacteria in fish: a review. Aquaculture, 160:177-203. 
5. Ringo, E. and Olsen, RE. (1999) . The effect of diet on aerobic bacterial Flora associated with intestine of Arctic charr (Salvelinus aplinus L.). J.Appl. Microbiol.,86 :22-28.

6. Ringo, E.; Bendiksen, H.; Wesmajervi, M.; Olsen, R.; Jansen, R. and Mikkelsen , H. (2000) . Lactic acid bacteria associated with the digestive tract of altantic Salmon ( Salmo salar L. ) J. Appl . Microbiol., 89: 317- 322.

7. Kvasnikov, El;Kovalenk,NK and Materinskaya, L.G .(1977) . Lactic acid bacteria of water fresh fish microbiology, 46:619-624.

8. Bucio Galindo, A; Hartemink, R; 'Schrama , JW; Verreth , JAJ. and Rombouts , FM.(2006).Presence of lactobacilli in the intestinal content of fresh water fish from a river and and from a farm with recirculation system .Food Microbiol., 23:476-482.

9. Tatsuro Hagi, D. T. ; Yasutada L. and Takayuki, H. ( 2004 ) .Diversity and seasonal changes in lactic acid bacteria in the intestinal tract of cultured fresh water fish . Applied Biochemistry, University of Tsukuba, 1-1-1 Ten - Nodai Tsukuba, Ibaraki: 305-8572.

10. Thapa, N; Pal, J and Tamang, JP.(2006). Phenotypic identification and Technological Properties of lactic acid bacteria isolated from traditionally processed fish products of the Eastern Himalayas. Int.J. food Microbiol., 107 ;33-38.

11. Hammes, WP.and Vogel, RF. (1995). The genus lactiobacillus. In: wood, BJB and Holzapfel, WH (eds), The lactic acid bacteria. Vol. 2, London, Blackie Academic. and Professional: 19-54 .

12. Cai. Y; Suyanandana .P; Saman, P.and Benno,Y. (1999). Classification and characterization of lactic acid bacteria isolated from the intestines of common carp and water fresh prawns. J .Gen .Appl . Microbiol ., 45 (4):177-184.

13. Khali, A; TKmechi, A.and Agh,N. (2009). Characterization of lactic Acid bacteria isolated from the intestines of common carp of west Azarbaijn, Iran. Jourual of Animal and Veterinary Advances. Vol 8 (6): 1162- 1164.

14. Ghanbari , M. ; Rezaci , M. ; Jami , M.; and Nazari , R. M .(2009).Isolation and characterization of lactobacillus species from intestinal contents of beluga (Huso huso ) and Persian sturgeon (Acipenser Persicns).Iranian Journal of Veterinary Research, Shiraz Uuiversity, 10(2)Ser . No. 27.

15. Parvath, S. N. and Puthuvallil, K. S.(2005). Biochemical Characterization of Lactic acid Bacteria isolated from fish and prawn. Journal of Culture Collections. 48-52.

16. Garvie, EI.(1984 ). Taxonomy and Identification of diary bacteria.in: Davies, FL .and Law , BA .(eds) Advanas in the microbiology and biochemistry of cheese and fermented milk. London: Elsevier Applied Science Pubishers, 35-65.

17. Hicks, SI.; Theodoropoulos , G.;Garrington , SD and Corfield , AP. (2000). The role of mucins in host-parasite interactions. Part 1- Protozoam Parasites. Parasitol Toduy $.16: 476-481$.

18. Stephen, AM. (1985). Effect of food on the intestinal microflora. In: Hunter, JO.and Alun, J. V.(eds.), Food and the gut. Sussex, England, Bailliere Tindall,. 57-77.

19. Onwehand, AC.;kirjavainen , PV. ; Gronlund, MM.; lsolauri, E.and Salminen, S.(1999).Adhesion of probiotic micro-organisms to intestinal mucus. Int. Dairy. J,9:623-630.

20. Fuller, R.(1989). Probiotics in man and animals. J. Appl. Bacteriol., 66:365 - 378. 